\author{
Maryna Shepel \\ Odessa Automobile and Road College \\ Odessa National Polytechnic University

\section{THE ROLE OF A FOREIGN LANGUAGE TEACHER IN THE PROCESS OF THE PROFESSIONAL TRAINING OF FUTURE EXPERTS OF THE MACHINE-BUILDING INDUSTRY}

C Shepel M., 2017

The article deals with the issue of the role of a foreign language teacher in the process of professional training of future experts of the machinebuilding industry during the period of studying in technical institutions. The viewspoints of leading scientists on the concept of «the professional training of future experts in engineering» are regarded. The author gives her own definition of the concept of "professional training of future experts in the machine-building industry». It is noted that the humanitarianization of technical education plays an important role in the professional training of future experts in the machine-building industry. Measures aimed at the professional training of future experts of the machine-building industry during the study of the discipline "A Foreign Language for the Professional Purposes»: working with professional texts and instructions from original sources, get acquainted with the documentation, playing various communicative situations, creating presentations on a given topic, conducting binary sessions.

Keywords: a foreign language teacher, vocational training, a future expert of the machine-building industry, technical institution.

\title{
Introduction
}

The development of Ukraine as an independent democratic state puts forward educational institutions of Ukraine new important challenges and requirements. An important factor of changing of the educational process is the integration of Ukraine to the European Union, strengthening relations with developed European countries, introduction of new educational technologies.

According to the European Framework of Reference for Languages and Concept of Teaching foreign languages the main aim of teaching a foreign language is the formation of communicative competence among the professionals, that means mastering a language as a way of intercultural communication, the development of skills to use a foreign language as a 


\section{Psychological and pedagogical problems of modern specialist formation}

tool in the dialogue of cultures and civilizations of the modern world [9]. Today's job market sets up a claim of experts of the machine-building industry who know a foreign language in a sufficient level as a means of communication. The topical question is the role of a foreign language teacher in the process of professional training of future experts of the machine-building industry.

The purpose of the article is to define activities that a foreign language teacher can use in the process of professional training of future experts of the machine-building industry in the period of their studying at a technical institution.

\section{Materials and methods}

The problem of training of experts in the engineering industry is reflected in the researches of O. Dzhedzhula, M. Kozyar, G.Raykovska, O. Gavrilyuk, A. Lytvyn, S. Lytvynchyk, Yu. Loboda, S. Mamrych, M. Fomina and others; the humanitarization of experts of engineering branch is investigated in the assignments of A. Kochubey, S. Korol. The personality development of professional, professional orientation and formation is considered in the researches of B. Avalos, S. Amelina, L. Vyhots'ky, E. Erikson, Ye. Klimov, O. Leont'yev, P. Makarenko, R. Pelekh, S. Rubinshteyn, L. Shneydera, O. Yermolayva, G. Yavors'ka.

Resourse books define the term «training» as: 1) supply of knowledge, skills and experience gained during the training, practice; 2) preparation of all necessary for something [4, p. 329].

In psychological and educational reference materials the term «training» is interpreted as: 1) the formation and enrichment of knowledge and skills which are necessary for the individual to adequately performance of special tasks. The meaning of training is revealed in its two meanings: a specific training organized by the formation of readiness to meet future challenges and how readiness - the existence of competence, knowledge and skills needed to successfully perform a certain set of tasks [2, p. 140]; 2) formation and enrichment of facilities, knowledge and skills necessary for a person to adequately perform specific tasks [8, p. 344].

In the scientific examinations of scientists (Yu. Loboda, A. Lytvyn, S. Litvinchuk, O. Ihnatyuk, M. Fomina) one can find different interpretations of the phenomenon of professional training of specialists of engineering profile.

So, Yu. Loboda understands professional training as the system of targeted measures ensuring the formation of professional orientation of a future expert, knowledge, skills and professional readiness that allow to work in a particular field of activity [7, p. 8].

According to O. Ignatyuk, professional training of a future engineer is a socio-pedagogical system, which is directed to the formation of value 
orientations of future specialist with the goal of personal and professional development and improvement [3, p. 16].

The scientist defines the requirements that apply to modern engineers under the Euro standard, so called «key qualifications». Among the major are the following requirements: communicativeness, responsibility, reflection, the ability to cooperate, professional autonomy, an ability of self-development, initiative, excessive professional activity, and the like. Creative autonomy, thus, is the part of key qualifications as a basis [3, p. 14].

By the definition of M. Fomina, psychocological and pedagogical training of future engineers of machine-building descriptions in the higher technical educational institutions is regarded as a specially organized process, aimed at mastering of psychological, pedagogical and managerial knowledge, abilities and skills, on the formation and development of personal and professionally important qualities needed in the future professional activity [1, p. 11].

Under the professional training of future experts of machine-building industry we understand the deliberate process of mastering the professional knowledge, knowledge about requirements posed by the society to the experts of the machine-building industry.

In our opinion, the humanitarization of the professional training of future experts of machine-building industry is very important.

A. Kochubey defines «the humanitarization of technical education» as the system of activities during the educational process, aimed at using in educational institutions, the capabilities of each item; the creation of favourable conditions for formation of intellectual, spiritually rich personality with well-developed general and professional culture of future engineers [6, p. 9].

According to the position S. Korol, knowledge of humanities are widely used in engineers' daily professional activities, including: communication with colleagues, customers, documentation, working with others concerning the profession, establishing interpersonal relationships in the team, etc. [5, p. 8].

\section{Results}

Thus, a leading role in the training of future experts of machinebuilding industry should belong to a foreign language teacher.

Own job experience as a foreign language teacher in Odessa Automobile and Road College of ONPU has given an opportunity to define the following activities aimed at professional training of future specialists in the period of studying of the subject «A Foreign Language for Professional Purposes»: working with specialized texts and instructions from primary 


\section{Psychological and pedagogical problems of modern specialist formation}

sources, review of documentation (drafting letters, reports, etc.), playing various communicative situations (communicative skills with colleagues, clients), creating presentations on a given subject, conducting binary studies.

\section{Discussion and conclusions}

Therefore, the activies that a foreign language teacher can use in the process of professional training of future experts of the machine-building industry is regarded in the article. Further study is required an investigation the role of reading comprehension of specialized texts during the subject «A Foreign Language for Professional Purposes».

\section{References}

1. Fomina, M. V. (2005). Strukturuvannja zmistu psykhologhopedaghoghichnoji pidghotovky majbutnikh inzheneriv mashynobudivnogho profilju [The structuring of the contents of psychological-and-pedagogical training of future engineers of machine-building description] (Candidate's thesis, M. Kotsyubynsky VSPU, Vinnytsia, Ukraine). (in Ukrainian)

2. Herasymova, N. Ye., Kasiarum, N. V., Korol, V. M., \& Savchekno, O. P. (2010). Slovnyk-dovidnyk z pedaghoghiky i psykhologhiji vyshhoji shkoly [Glossary Directory of pedagogy and psychology of higher school]. Cherkasy: B. Khmeljnycjkyj ChNU Publ. (in Ukrainian)

3. Ighnatjuk, O. A. (2010). Teoretychni ta metodychni osnovy pidghotovky majbutnjogho inzhenera do profesijnogho samovdoskonalennja $v$ umovakh tekhnichnogho universytetu [Theoretical and methodical bases of preparation of the future engineer to professional self-perfection in conditions of technical university] (Expended abstract on Doctor's thesis, H. S. Skovoroda KhNPU, Kharkiv, Ukraine). (in Ukrainian)

4. Ivchenko, A. O. (2008). Tlumachnyj slovnyk ukrajinsjkoji movy [Thesaurus of the Ukrainian language]. Kharkiv: Folio. (in Ukrainian)

5. Korol, S. V. (2011). Profesijna sprjamovanistj ghumanitarnoji pidghotovky fakhivciv inzhenernogho profilju $v$ universytetakh [Professional orientation of humanitarian preparation of engineering profile specialists in the universities] (Candidate's thesis, Volodymyr Hnatiuk TNPU, Ternopil, Ukraine). (in Ukrainian)

6. Kochubey, A. V. (2010). Ghumanitaryzacija pidghotovky majbutnikh inzheneriv $u$ vyshhykh navchaljnykh zakladakh zasobamy narodoznavstva [Humanization of training future engineers in higher educational establishments by ethnography methods] (Candidate's thesis, M. Kotsyubynsky VSPU, Vinnytsia, Ukraine). (in Ukrainian)

7. Loboda, Yu. G. (2010). Pedaghoghichni umovy vykorystannja komp'juterno-integhrovanykh tekhnologhij u procesi pidghotovky majbutnikh inzheneriv [Pedagogical conditions of implementing computer- 
integrated technologies in the process of training the future engineers] (Candidate's thesis, K. D. Ushinsky SUNPU, Odessa, Ukraine). (in Ukrainian)

8. Mizherikov, V. A. (1998). Psikhologo-pedagogicheskii slovar dlia uchitelei $i$ rukovoditelei obshcheobrazovatelnykh uchrezhdenii [Psychological and pedagogical dictionary for teachers and heads of general educational institutions]. Rostov-on-Don: Feniks. (in Russian)

9. Nikolayeva, S. Yu. (Ed.). (2003). Zagal'noyevropejs'ki Rekomendaciyi z movnoyi osvity: vyvchennya, vykladannya, ocinyuvannya [Common European Framework of Reference for Languages: Learning, Teaching and Assessment]. Kyiv: Lenvit. (in Ukrainian)

Марина Шепель. Роль викладача іноземної мови у процесі професійної підготовки майбутніх фахівців машинобудівної галузі. У статті розглянуто питання ролі викладача іноземної мови у прочесі професійної підготовки майбутніх фахівиів машинобудівної галузі у період навчання у технічних вишах. Розглянуто погляди провідних науковців стосовно поняття «професійна підготовка майбутніх фахівців інженерного профілю». Автором надано власне визначення поняття «професійна підготовка майбутніх фахівиів машинобудівної галузі». Зазначено, щзо важливого значення у професійній підготовиі майбутніх фахівиів машинобудівної галузі відіграє ї гуманітаризаиія. Визначено заходи, спрямовані на професійну підготовку майбутніх фахівців машинобудівної галузі у період вивчення дисципліни «Іноземна мова за професійним спрямуванням»: робота з фаховими текстами та інструкиіями з першоджерел, ознайомлення з документаиією, розігрування різних комунікативних ситуаџій, створення презентаџій на задану тематику, проведення бінарних занять.

Ключові слова: викладач іноземної мови, професійна підготовка, майбутній фахівець машинобудівної галузі, технічний ВНЗ.

Marina Shepel. Rola nauczyciela języka obcego w trakcie szkolenia zawodowego przyszlych specjalistów z branży inżynierskiej. $W$ artykule poruszona zostata kwestia roli nauczyciela języka obcego $w$ trakcie szkolenia zawodowego przysztych specjalistów z branży inżynierskiej podczas studiów na uczelniach technicznych. Przedstawione zostaty poglady uznanych, czołowych naukowców na temat «profesjonalnego szkolenia przysztych specjalistów o profilu inżynierskim». Autor podaje własna definicję pojęcia «ksztatcenia przysztych specjalistów z branży inżynierskiej». Należy zauważyć, że tego typu ksztatcenie odgrywa istotna role $w$ humanizacji tego kierunku. Środki umożliwiajace szkolenie przyszlych specjalistów z branży inżynieryjnej $w$ trakcie studiów «Języka 


\section{Psychological and pedagogical problems of modern specialist formation}

obcego o kierunku profesjonalnym» to: praca ze źródłowym tekstem zawodowym, zapoznanie sie $z$ dokumentacja, tworzenie wielorakich sytuacji komunikacyjnych, tworzenie prezentacji na dany temat, prowadzenie wykładów.

Słowa kluczowe: nauczyciel języka, szkolenia, przyszłość przemystu, specjalista inżynierii, uczelnia techniczna.

Received 24.05.2017

Information about the author:

Shepel Maryna - Doctor of Philosophy in Pedagogy, Lecturer, Odessa Automobile and Road College Odessa National Polytechnic University. 